\title{
POTENTIAL AND ECONOMIC DIMENSION OF RENEWABLE ENERGY SOURCES IN DIYARBAKIR
}

\author{
${ }^{*}$ Mustafa BULUT ${ }^{1}$, Hasan BAYINDIR ${ }^{2}$, Hasan ARSLAN ${ }^{3}$ \\ ${ }^{* 1}$ Dicle University, Vocational School of Social Sciences, Department of Management and Organisation, 21280 \\ Diyarbakır/Turkey, mbulut@dicle.edu.tr \\ ${ }^{2}$ Dicle University, Vocational School of Technical Sciences, Department of Machinery and Metal Technologies, \\ 21280 Diyarbakır/Turkey, hbayindir@dicle.edu.tr \\ ${ }^{3}$ Dicle University, Vocational School of Social Sciences, Department of Accounting and Tax Applications, [ \\ 21280 Diyarbakır/Turkey, hasan.arslan@dicle.edu.tr \\ *mbulut@dicle.edu.tr
}

\begin{abstract}
It is considerably difficult to achieve sustainable development nowadays because non-renewable energy sources are rapidly running out of reserves due to extensive consumption. For sustainable development, serious social and environmental policies should be constituted and implemented in harmony to reduce the minimum economic and social costs of development. From this point of view, energy sources are the main axis of these policies especially in the countries with limited reserves or dependent on foreign reserves in terms of high cost imposed on the country's economy and also the damage to the environment.

High population growth, migration waves, energy-intensive new investments, technological improvements, and excessive energy consumption habits increase the energy consumption. Countries are in constant search to avoid the negative effects that may arise in economic and social life due to future energy crisis. Therefore, countries have contemporarily inclined to renewable energy sources such as solar, wind, and water.

In this study, the current established capacity of solar, hydraulic, biomass, wind and geothermal energy in Diyarbaklr has been studied. It is aimed to introduce the potential and economic dimension of renewable energy sources, especially solar energy in Diyarbakır.

Data in regional, national and international scale have been obtained and evaluated with its economic dimension.
\end{abstract}

Keywords: Renewable energy, solar energy, Diyarbakır, development, economic dimension

\section{Introduction}

All the countries, which are willing to provide sustainable development, have been in serious quest for years to reduce the economic, social and environmental cost of development. As the need for energy use, which is an indispensable part of development, is increasing directly proportional to development, it has been required to incline to $100 \%$ domestic renewable energy sources instead of conventional fuels that cause great economic and environmental cost and foreign dependency. Studies on the use of renewable energy sources, especially solar energy, have gained momentum especially since the 1970s due to increasing dependency on fossil energy sources, gradually declining oil reserves and increasing oil prices due to the oil crisis. 
"Since 1950, the world population has increased about three times, while energy demand has increased six times" [1]. The world population is projected to be 8.6 billion in 2030 and 9.8 billion in 2050 . The population of Turkey will be 96 billion in 2050 [2].

When Turkey's potential for renewable energy sources is taken into account, the utilization of its own renewable energy sources is quite low despite the large sums it pays to other countries for energy purchasing.

The state of Diyarbakır, which is one of the most sun-dense cities in the country, is not different from Turkey [3]. The main source of energy used in the city, which is a metropolitan area and has a population of nearly 2 million, was fossil fuel until recently. Hydraulic energy source ranked the $2^{\text {nd }}$. Today, imported natural gas energy sources have replaced the first place of fossil-based sources. The city, which is well above the country average in terms of the potential of renewable energy sources, benefits from these renewable energy sources, especially solar energy, slightly. Although Diyarbakır province needs to contribute to the country's economy with its potential, it cannot make a significant contribution.

\section{Material and Method}

The study was carried out in Diyarbakır province. In this study, Turkey and Diyarbakır data of the Turkish Statistical Institute, General Directorate of State Hydraulic Works and General Directorate of Renewable Energy were used predominantly.

\section{Current Situation of Turkey in terms of Renewable Energy Sources}

In order to make precise evaluations of the potential of renewable energy sources in the province of Diyarbakir, firstly the current situation of our country should be known.

Although Turkey is a very rich country in terms of renewable energy sources, especially solar energy, Turkey does not have sufficient production potential, so it supplies about $80 \%$ of its energy need from abroad. According to Turkish Statistical Institute (TURKSTAT) data, in 2015 [4], Turkey imported \$ $37,843,294,000$ of energy consisting mineral fuels, mineral oils and their distillation products, which was an important share in its total of $\$ 207,234,359,000$ import. According to these results, Turkey's share of energy imports in its total imports is still around $20 \%$, despite the $31.1 \%$ decrease in energy prices due to reductions in natural gas prices in addition to the previous year's oil prices.

The general situation in the world about renewable energy source production and consumption seems to be the same like as Turkey.

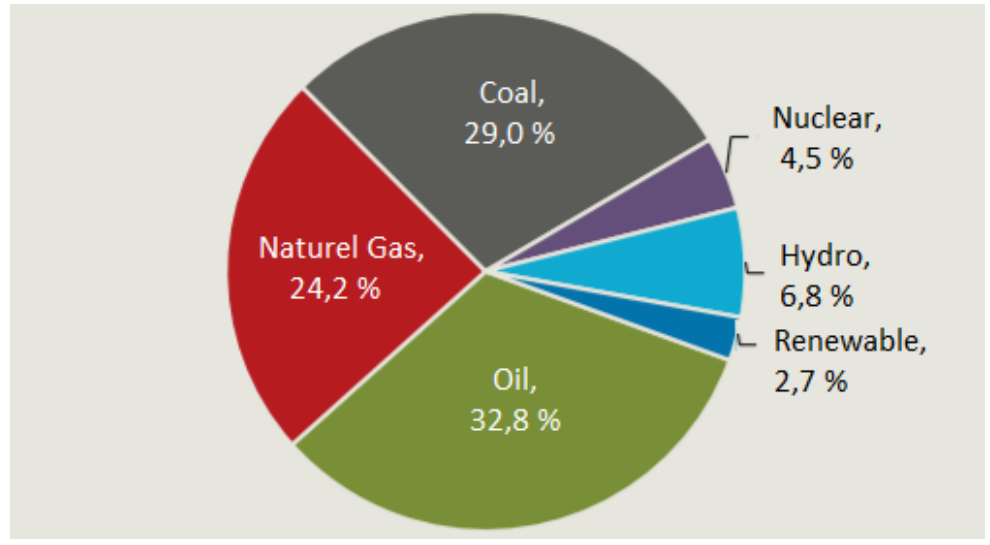

Figure 3.1 Global primary energy consumption rates in 2015 [5]

The import dependency rate of our country on petroleum is $93.6 \%$ and the import dependency rate on natural gas is $99.2 \%$ [6]. These figures require our country to use the potential of renewable energy sources in the best way.

\subsection{Turkey's Solar Energy Potential}

Turkey's Solar Energy Potential is given in Fig. 3.2. 


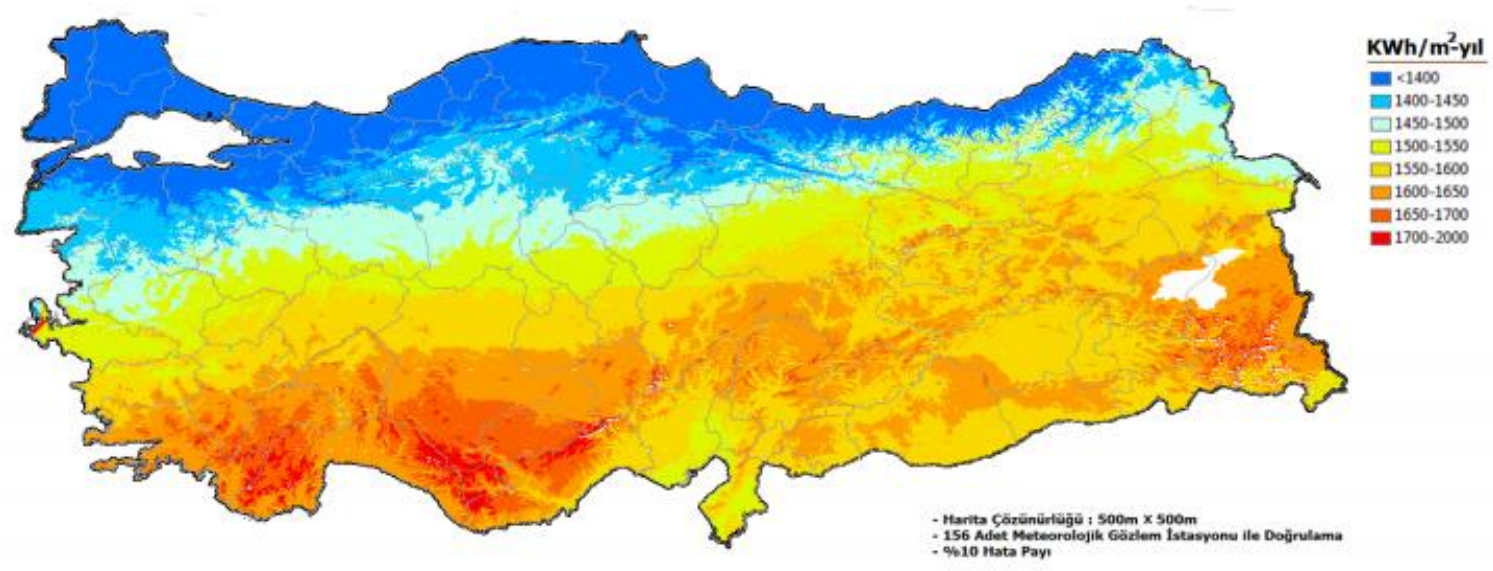

Figure 3.2 Turkey's solar energy potential [7].

Turkey has an average annual solar radiation intensity of $1311 \mathrm{kWh} / \mathrm{m}^{2}$ and an average annual insolation period of 2640 hours [8]. This figure corresponds to a daily power of $3.6 \mathrm{kWh} / \mathrm{m}^{2}$ and a time of about 7.2 hours a day, 110 days of insolation period in total [9]. Average Global Solar Radiation is given as $1520 \mathrm{kWh} / \mathrm{m}^{2}$-year. Up to $63 \%$ of the country's surface area can benefit from solar energy technically and economically during the 10 months of the year. Despite this great potential, the level of harnessing solar energy is very low [10].

\subsection{Turkey's Wind Energy Potential}

The wind energy potential of Turkey is shown in table 3.1.

Table 3.1 Turkey's wind energy potential [11]

\begin{tabular}{lcccr}
\hline $\begin{array}{c}\text { Resource } \\
\text { Potential }\end{array}$ & Wind Class & $\begin{array}{c}\text { Annual Wind } \\
\text { Power Density } \\
\left(\mathbf{W} / \mathbf{m}^{2}\right)\end{array}$ & $\begin{array}{c}\text { Annual Wind } \\
\text { Speed } \\
(\mathbf{m} / \mathbf{s})\end{array}$ & $\begin{array}{c}\text { Total Capacity } \\
(\mathbf{M W})\end{array}$ \\
\hline Good & 4 & $400-500$ & $7.0-7.5$ & $29,259.36$ \\
Fantastic & 5 & $500-600$ & $7.5-8.0$ & $12,994.32$ \\
Excellent & 6 & $600-800$ & $8.0-9.0$ & $5,399.92$ \\
Extraordinary & 7 & $>800$ & $>9.0$ & 195.84 \\
& TOTAL CAPACITY & & $\mathbf{4 7 , 8 4 9 . 4 4}$ \\
\hline
\end{tabular}

According to the table, the $195.84 \mathrm{MW}$ of total energy capacity is generated by the annual wind power density over 800 seems to be quite low compared to the 29,259.36 MW of energy generated by the wind with good source potential, wind class 4 , annual wind speed 7.0 to 7.5 .

\subsection{Turkey's Geothermal Energy Potential}

Turkey is a country with a very high geothermal potential due to its geographical location. The geothermal potential in Turkey is theoretically 31,500 MW [12].

According to the data by the Ministry of Energy and Natural Resources (MENR) of the year 2016, 5,000 MW of thermal energy was acquired with newly opened wells. According to this report, the number of sites suitable for electricity generation has risen to 25 , greenhouse heating to 3,931 acres, residential heating to the equivalent of 114,567 homes, electricity generation to $820 \mathrm{MW}$, and country visible thermal capacity to $14,000 \mathrm{MW}[12]$.

\subsection{Turkey's Biomass Energy Potential}

It is estimated that the biomass waste potential of Turkey is about 8.6 million tons equivalent petroleum (MTEP), and the amount of biogas that can be produced is 1.5-2 MTEP. It is projected that the biomass power plant installed power target of the country will be $1000 \mathrm{MW}$ in 2023 [13]. 


\subsection{Turkey's Hydraulic Energy Potential}

Hydraulic energy is one of the renewable energy sources. It is provided by converting the potential energy of the water that stored in the dams, into kinetic energy. Hydropower plants are used for this purpose. Hydraulic Energy Potential of Turkey is given in table 3.2.

Table: 3.2 Turkey's hydraulic energy potential [14]

\begin{tabular}{lcccc}
\hline \multicolumn{1}{c}{ Source } & $\begin{array}{c}\text { Theoretical } \\
\text { Hydroelectric } \\
\text { Potential } \\
(\mathbf{k W h} / \text { year })\end{array}$ & $\begin{array}{c}\text { Feasible } \\
\text { Hydroelectric } \\
\text { Potential } \\
(\mathbf{k W h})\end{array}$ & $\begin{array}{c}\text { Economic } \\
\text { potential } \\
(\mathbf{k W h} / \text { year })\end{array}$ & $\begin{array}{c}\text { Projected Economic } \\
\text { Potential with New } \\
\text { Projects } \\
(\mathbf{k W h} / \text { year })\end{array}$ \\
\hline $\begin{array}{l}\text { Hydraulic } \\
\text { Energy }\end{array}$ & 433 billion & 216 billion & 158 billion & 180 billion \\
\hline
\end{tabular}

According to General Directorate of State Hydraulic Works data, Turkey's technically feasible hydroelectric potential is $1.5 \%$ of world potential and $17.6 \%$ of European potential. Although Turkey has the greatest potential following Russia in European countries, it is not in a good position to benefit from this potential [14]. Turkey's hydroelectric potential is given in Figure 3.3.

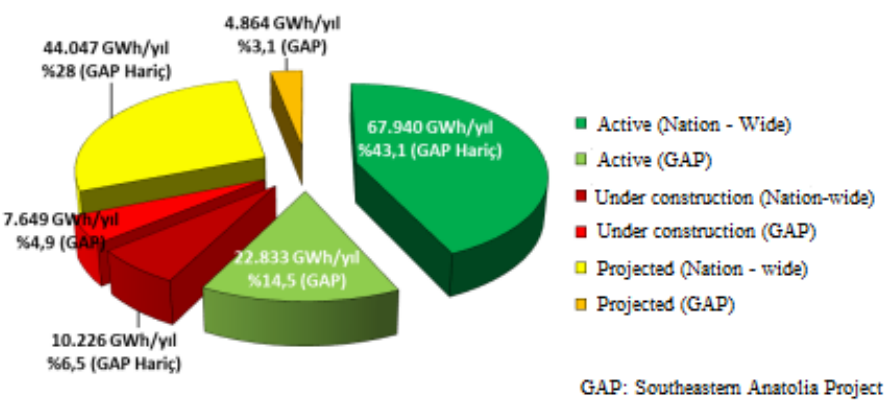

Figure 3.3 Turkey's hydroelectric potential according to developed projects (158 billion kwh) [14].

When Fig. 3.3 is analysed, it is seen that only $57.6 \%$ of the total potential is active compared to the developed projects.

\section{Turkey's Targets for Renewable Energy Sources}

Turkey's targets for renewable energy resources in 2023 , on the $100^{\text {th }}$ anniversary of the Republic, are as the following [15]:

1. The entire economically feasible hydroelectric potential of Turkey will be used in generating electricity $(34,000 \mathrm{MW})$.

2. 20,000 MW of wind energy capacity will be in operation.

3. Solar power capacity of at least $5000 \mathrm{MW}$ will be reached.

4. At least $1000 \mathrm{MW}$ geothermal power plant will be constructed.

5. The established capacity of the biomass will be $1000 \mathrm{MW}$.

\section{Renewable Energy Sources of Diyarbakır Province}

We have seen five different sources of energy as renewable energy sources in Diyarbakır Province. These can be listed as solar energy, wind energy, geothermal energy, biomass energy and hydraulic energy. However, as shown below, it is seen that the province is rich in terms of the potential of solar, hydraulic and biomass energy sources but the potential of wind and geothermal energy is low.

\subsection{Solar Energy}

It is understood that Diyarbakır is rich in terms of solar energy when considering the average insolation periods and global radiation values shown in the Solar Energy Potential Atlas (GEPA) published by the General Directorate of Renewable Energy [7]. The Global Solar Radiation Distribution of Diyarbakır province is given in GEPA in Fig. 5.1. 

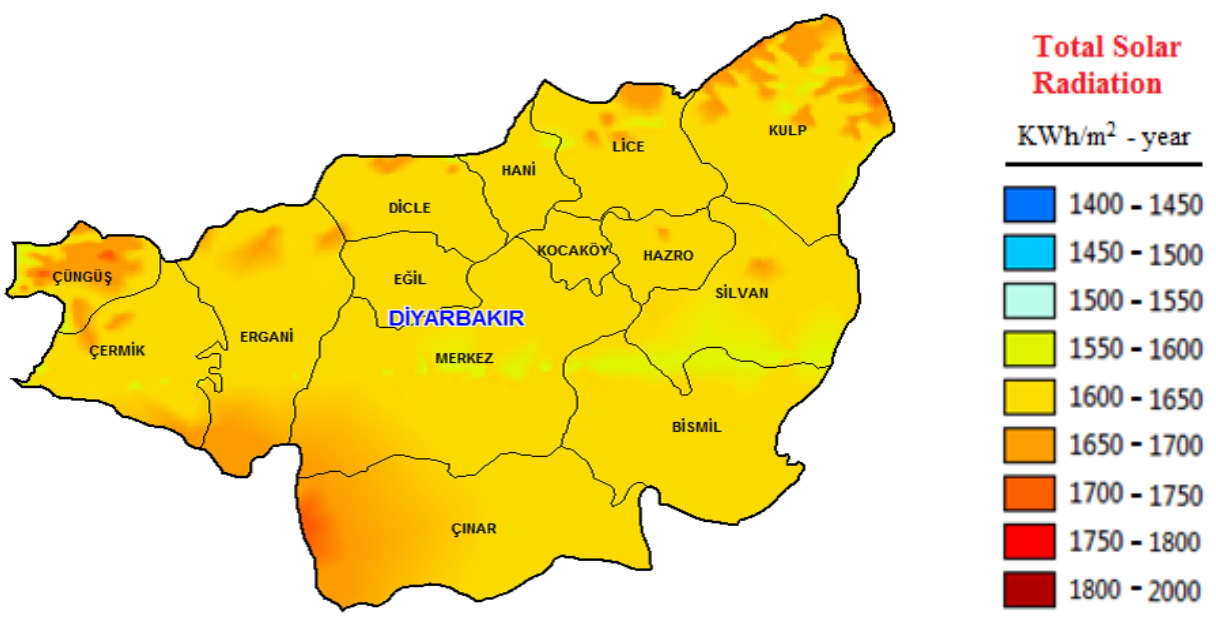

Figure 5.1 Global Solar Radiation Distribution [7]

Diyarbakir is located between $37^{\circ}-55^{\circ}$ north latitudes and $40^{\circ}-14^{\circ}$ east longitudes. The annual average solar radiation of the province is $1,584 \mathrm{kWh} / \mathrm{m}^{2}$ (average of $4.34 \mathrm{kWh} / \mathrm{m}^{2}$ per day) and the average insolation period is 2898 hours / year (daily average of 7.93 hours / day).

The global radiation values of Diyarbakır Province by months are given in the graphic below. According to the graphic, the highest radiation values are in June, July, May and August respectively, and the lowest radiation values are in December, January, November and February, respectively. Diyarbakır Global Radiation values are given in fig. 5.2.

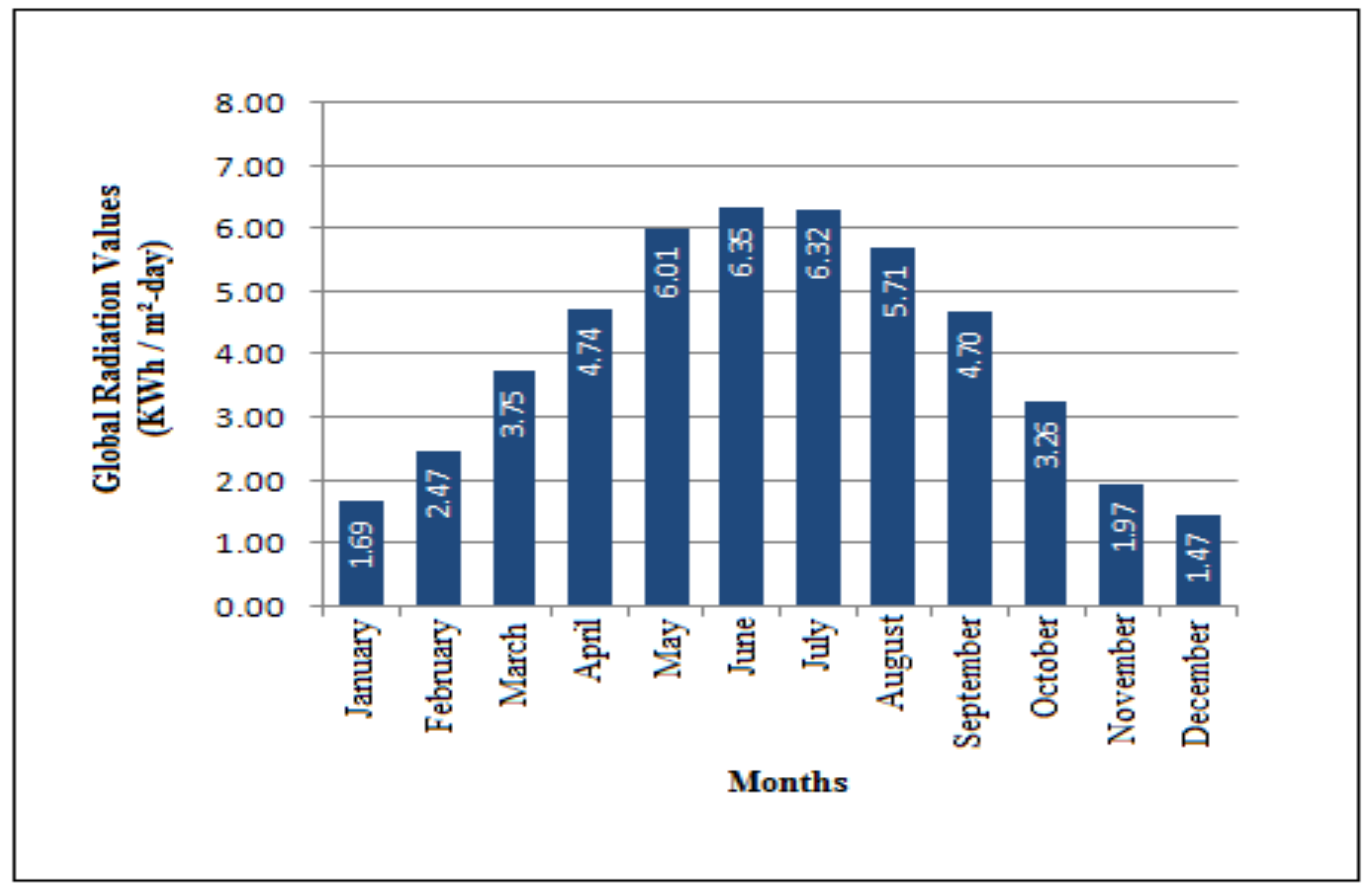

Figure 5.2 Diyarbakır Global Radiation Values (KWh / $\mathrm{m}^{2}$-day) [7]

It is seen that the month with the maximum insolation is June when the radiation value is the highest and the month with the least insolation is December when the radiation value is the lowest.

In the study conducted by Kılıç and et. al. [16], it was determined that the average global radiation value of Diyarbakır province is $3.8 \mathrm{kWh} / \mathrm{m}^{2}$ per day. According to this, it was determined that the average daily radiation value of Diyarbakır province is $0.2 \mathrm{kWh} / \mathrm{m}^{2}$ more than the average daily global radiation values of the country and it receives $73 \mathrm{kWh}$ more solar energy per $\mathrm{m}^{2}$ per year. 


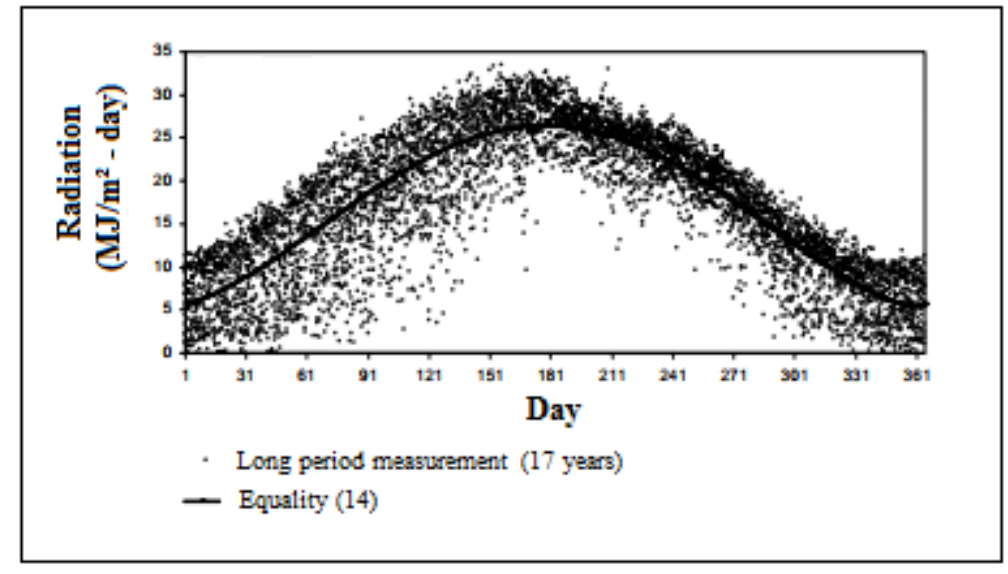

Figure 5.3. Change of Total Daily Horizontal Solar Radiation through the Year [17]

\subsubsection{Photovoltaic systems}

Photovoltaic systems are systems that convert solar energy directly into electric energy. They have become one of the most promising applications in solar energy applications in recent years because they do not need any external fuel source and they have the ability to easily integrate with other systems and offer a wide alternative in terms of use.

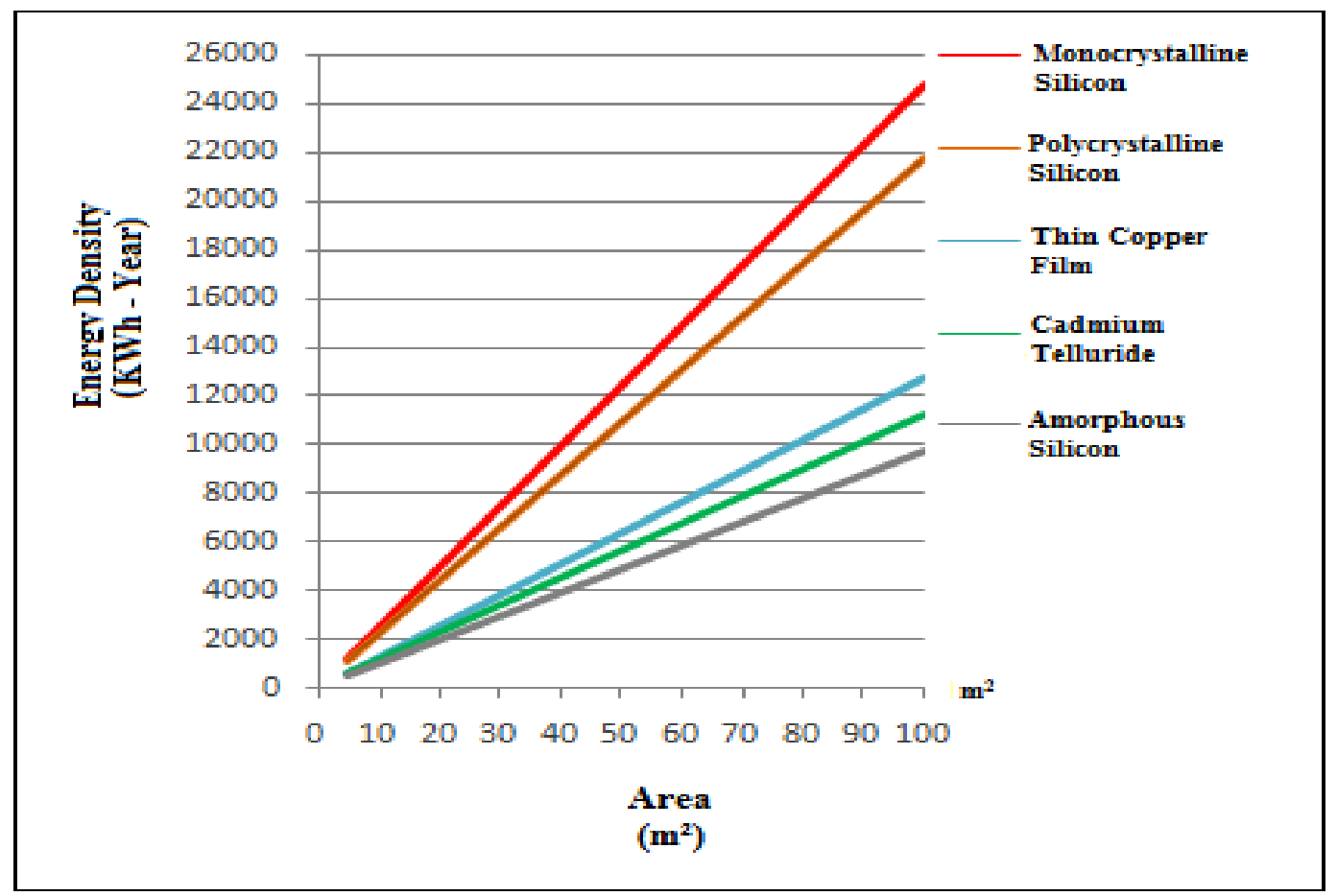

Figure 5.4 Diyarbakır PV type energy producible area (kwh-year) [7]

The amount of energy that can be produced in an area of $100 \mathrm{~m}^{2}$ in Diyarbakır with a photovoltaic method is shown at Fig. 5.4.

\subsubsection{Diyarbakır Solar Energy Power Plants}

As of 2017, the established capacity of the current active solar power plants and companies in Diyarbakir province are given in Tab. 5.1. As you can see on the table, the established power is $2.54 \mathrm{MW}$ in the province. 
Table 5.1 Active solar power plants established in Diyarbakır Province [18]

\begin{tabular}{llllc}
\hline & Name of the Power Plant & $\begin{array}{l}\text { Type of } \\
\text { Facility }\end{array}$ & \multicolumn{1}{c}{ Company } & $\begin{array}{c}\text { Establish } \\
\text { ed Power } \\
\text { (MW) }\end{array}$ \\
\cline { 2 - 5 } & Dimer Marble SPP & Solar & Dimer Marble & 1,00 \\
$\begin{array}{l}\text { ESTABLISHED } \\
\text { PLANTS }\end{array}$ & DİSKİ Gözeli Basin SPP & Solar & $\begin{array}{l}\text { D.Bakır Metropolitan } \\
\text { Municipality }\end{array}$ & 0,60 \\
& Diyarbakır Sümerpark SPP & Solar & $\begin{array}{l}\text { D. Bakır } \\
\text { Metropolitan } \\
\text { Municipality }\end{array}$ & 0,46 \\
& $\begin{array}{l}\text { Gap International } \\
\text { Agricultural Research SPP }\end{array}$ & Solar & GAPUTAEM & 0,24 \\
& Dicle University SPP & Solar & Dicle University & 0,24 \\
\hline
\end{tabular}

In addition, there are 3 Solar Power Plants, which is under construction, in power of 2,23 MW.

\subsection{Wind Energy}

Diyarbakır Province does not have enough sources in terms of wind energy. As it is known, the most important points to take into consideration about the rationalization of wind power plant investments are;

- The wind speed at $50 \mathrm{~m}$ height should be $7 \mathrm{~m} / \mathrm{s}$ or above [11].

- The capacity factor at 50 meters should be $35 \%$ or over [11].

When province based REPA (Wind Energy Potential Atlas - WEPA) published by the General Directorate of Renewable Energy (2017) is analysed, it has been seen that the wind speed at $50 \mathrm{~m}$ height in Diyarbakır Province is only $6.5 \mathrm{~m} / \mathrm{s}$ and above in limited areas, and $4.5 \mathrm{~m} / \mathrm{s}$, in the rest of the province. It is also seen that the height speed capacity is not different and the capacity factor at 50 meters is between $10 \%$ and $25 \%$ [11]. The power capacity of the wind power plant that can be established in Diyarbakır Province is given in Tab. 5.2.

Table 5.2 Wind energy power plant capacity to be established in Diyarbakır Province [11]

\begin{tabular}{cccc}
\hline $\begin{array}{c}\text { Wind Power at 50 } \mathbf{m} \\
\left(\mathbf{W} / \mathbf{m}^{2}\right)\end{array}$ & $\begin{array}{c}\text { Wind Speed at } \mathbf{5 0} \mathbf{~ m} \\
(\mathbf{m} / \mathbf{s})\end{array}$ & $\begin{array}{c}\text { Total Area } \\
\left(\mathbf{k m}^{2}\right)\end{array}$ & $\begin{array}{c}\text { Total Established Power } \\
(\mathbf{M W})\end{array}$ \\
\hline $\mathbf{3 0 0}-\mathbf{4 0 0}$ & $6.8-7.5$ & 110,03 & 550,16 \\
$\mathbf{4 0 0}-\mathbf{5 0 0}$ & $7.5-8.1$ & 16,98 & 84,88 \\
$\mathbf{5 0 0}-\mathbf{6 0 0}$ & $8.1-8.6$ & 0,00 & 0,00 \\
$\mathbf{6 0 0}-\mathbf{8 0 0}$ & $8.6-9.5$ & 0,00 & 0,00 \\
$>\mathbf{8 0 0}$ & $>9.5$ & 0,00 & 0,00 \\
& & $\mathbf{1 2 7 , 0 1}$ & $\mathbf{6 3 5 , 0 4}$ \\
\hline
\end{tabular}

As seen in Tab. 5.2, the wind energy potential of Diyarbakır Province is not sufficient.

\subsection{Geothermal energy}

According to the Geothermal Energy Atlas published by the General Directorate of Renewable Energy, the sources with temperatures between $70-100{ }^{\circ} \mathrm{C}$ are concentrated in the Aegean, Central Anatolia and Eastern Anatolia Regions [19]. The Geothermal Energy Source in the province of Çermik in Diyarbakır is given in Tab. 5.3.

Table 5.3 Geothermal energy source in Çermik, Diyarbakır [20]

\begin{tabular}{llccccc}
\hline Province & $\begin{array}{l}\text { Geothermal } \\
\text { Area }\end{array}$ & $\begin{array}{c}\text { Depth } \\
(\mathbf{m})\end{array}$ & $\begin{array}{c}\text { Number } \\
\text { of Wells }\end{array}$ & $\begin{array}{c}\text { Temperature } \\
\left({ }^{\mathbf{0}} \mathbf{C}\right)\end{array}$ & $\begin{array}{c}\text { Flow rate } \\
(\text { It } / \text { sec })\end{array}$ & Purpose \\
\hline Diyarbakır & Çermik & $200-250$ & 6 & 51 & $30-50$ & Spa \\
\hline
\end{tabular}


Geothermal energy source located in Çermik, Diyarbakır is in low temperature, it contains 36 kinds of minerals at a distance of 100 meters from the users.

\subsection{Biomass Energy}

Biomass energy is considered as a significant source of energy in terms of being a renewable and sustainable resource. The use of biomass is gaining increasingly importance to solve the energy problem especially in rural areas because energy resources such as oil, coal, natural gas are limited, and they damage the environment, Potential and Calorific Values of Biomass Sources of Diyarbakır Province are given in Tab. 5.4.

Table 5.4 Potential and calorific values of biomass sources of Diyarbakır Province [21]

\begin{tabular}{lcccc}
\hline $\begin{array}{l}\text { Biomass } \\
\text { Resource }\end{array}$ & $\begin{array}{c}\text { Cultivated } \\
\text { Area } \\
\text { (hectare) }\end{array}$ & $\begin{array}{c}\text { Production } \\
\text { (ton) }\end{array}$ & $\begin{array}{c}\text { Average Dry Biomass } \\
\text { Amount / } \\
\text { Minimum Waste } \\
\text { Amount (tons) }\end{array}$ & $\begin{array}{c}\text { Calorific Value } \\
\text { (TEP) }\end{array}$ \\
\hline $\begin{array}{l}\text { Field Crops } \\
\text { Orchards }\end{array}$ & $635.178,3$ & 149.401 & $17.467 .403,3$ & $6.986 .961,3$ \\
$\begin{array}{l}\text { Vegetable } \\
\text { Garden }\end{array}$ & 254.999 & 461.753 & 12.279 & $4.911,60$ \\
Oil seeds & 169.797 & 94.122 & 37.649 \\
& 830.265 & 441.908 & $22.271,89$ & $779.516,21$ \\
\end{tabular}

* The calorific value of $1 \mathrm{~kg}$ biodiesel is taken as $35 \mathrm{MJ}$.

When the calorific values of crops are taken into consideration, it is seen that the calorific values of especially legumes, cereals, industrial crops, oil seeds and forage crops are very high and this creates a potential that cannot be neglected in biomass energy production together with other orchard and horticultural products and oil seeds.

\subsection{Hydraulic Energy}

Diyarbakır Province is home to hydroelectric power generation, which contributes significantly to the country's economy, with the Hydroelectric Powers (HEPPs) built on the Firat and Tigris rivers, two of the country's most fertile rivers [22]. HEPPs established in Diyarbakır province and the total energy they provide is given in Tab. 5.5.

Table: 5. HEPPs established in Diyarbakır Province and total energy they provide [18]

\begin{tabular}{lcc}
\hline Name of HEPP & $\begin{array}{c}\text { Total Established Power } \\
(\mathbf{M W})\end{array}$ & Total Energy (GWh) \\
\hline Dicle & 110 & 298 \\
Karakaya & 1800 & 7354 \\
Kralkızı & 95 & 146 \\
Batman & 198 & 483 \\
Kulp 1 & 23 & 78 \\
Kulp 4 & 12 & 39 \\
Çağlayan Regulator and HEPP & 12 & 40 \\
Total & $\mathbf{2 2 5 0}$ & $\mathbf{8 4 3 8}$ \\
\hline
\end{tabular}

Dicle Dam and HEPP, with a power of $110 \mathrm{MW}$, generate electricity of 298 million kWh per year and contribute 2 million 980 thousand TL to the country's economy at the 1997 prices and contribute 9 million 800 thousand TL more with the irrigation per year - reaching 12 million 780 thousand TL in total [23].

Kralkızı Hydroelectric Power Plant has made a significant contribution to the economy by generating 146 GWh electricity Worthing 1 million 460 thousand TL at the 1997 prices. 
Karakaya Dam, with a power of $1,800 \mathrm{MW}$, generates $7.354 \mathrm{GWh}$ of electricity per year, a significant contribution to the economy Worthing of 735 million 400 thousand TL at the 1997 prices.

\section{Power Plants Established and Projected in Diyarbakır Province}

There are 7 hydropower and 5 solar power plants in Diyarbakir with a total established capacity of 2252.54 MW. The HEPPs and solar power plants, which are under construction, have production licence, have pre-licence are presented in the following table.

Table 6.1 Power plants established and projected in Diyarbakır Province [18]

\begin{tabular}{|c|c|c|c|c|}
\hline $\begin{array}{l}\text { Current } \\
\text { Situation }\end{array}$ & Name of the Power Plant & $\begin{array}{l}\text { Type of } \\
\text { Facility }\end{array}$ & Company & $\begin{array}{l}\text { Establish } \\
\text { ed Power } \\
\text { (MW) }\end{array}$ \\
\hline \multirow{12}{*}{$\begin{array}{l}\text { Established } \\
\text { Power Plants }\end{array}$} & Karakaya Dam and HEPP & Hydroelectric & EÜAȘ & 1.800 \\
\hline & Batman Dam and HEPP & Hydroelectric & EÜAŞ & 198 \\
\hline & Dicle Dam and HEPP & Hydroelectric & EÜAŞ & 110 \\
\hline & Kralkızı Dam and HEPP & Hydroelectric & EÜAŞ & 95 \\
\hline & Kulp 1 HEPP & Hydroelectric & Yildizlar Energy & 23 \\
\hline & Kulp 4 HEPP & Hydroelectric & Y1ldizlar Energy & 12 \\
\hline & Çağlayan Regulator and HEPP & Hydroelectric & Ate Energy & 12 \\
\hline & Dimer Marble SPP & Solar & Dimer Marble & 1.00 \\
\hline & DİSKİ Gözeli Basin SPP & Solar & $\begin{array}{l}\text { D.Bakır } \\
\text { Metropolitan } \\
\text { Municipality }\end{array}$ & 0,60 \\
\hline & Diyarbakır Sümerpark SPP & Solar & $\begin{array}{l}\text { D.Bakır } \\
\text { Metropolitan } \\
\text { Municipality }\end{array}$ & 0,46 \\
\hline & $\begin{array}{l}\text { Gap International Agricultural } \\
\text { Research SPP }\end{array}$ & Solar & GAPUTAEM & 0,24 \\
\hline & Dicle University SPP & Solar & Dicle University & 0,24 \\
\hline \multirow{6}{*}{$\begin{array}{l}\text { Under } \\
\text { Construction } \\
\text { Power Plants }\end{array}$} & Silvan Dam and HEPP & Hydroelectric & EÜAȘ & 160 \\
\hline & Arfem Alüminyum SPP & Solar & Arfem Alüminyum & 0,99 \\
\hline & Karlis BİMS SPP & Solar & Karlis Bims & 0,64 \\
\hline & Diyarbakır Intercity Terminal & Solar & D.Bakır & 0,60 \\
\hline & Operations SPP & & $\begin{array}{l}\text { Metropolitan } \\
\text { Municipality }\end{array}$ & \\
\hline & DİSKİ HEPP & Hydroelectric & $\begin{array}{l}\text { D.Bakir } \\
\text { Metropolitan } \\
\text { Municipality }\end{array}$ & 0,34 \\
\hline \multirow{2}{*}{$\begin{array}{l}\text { Licensed } \\
\text { Power Plants }\end{array}$} & Metin Regulator and HEPP & Hydroelectric & - & 50 \\
\hline & Dicle Şahaban HEPP & Hydroelectric & - & 26 \\
\hline \multirow{3}{*}{$\begin{array}{l}\text { Pre-Licensed } \\
\text { Power Plants }\end{array}$} & Birsu 1 and 2 HEPP & Hydroelectric & $\begin{array}{l}\text { Silvan Elektrik } \\
\text { üretim }\end{array}$ & 88 \\
\hline & Dipni Dam and HEPP & Hydroelectric & - & 80 \\
\hline & Çayönü and Derya HEPP & Hydroelectric & Yildizlar Energy & 37 \\
\hline
\end{tabular}

The power of established power plants in Diyarbakır is $2252.54 \mathrm{MW}$. The electricity plants in Diyarbakır, which are 12 in total, generate approximately $7.460 \mathrm{GW}$ of electricity per year. This is 2,80 $\%$ of the total established power and $2.92 \%$ of the consumption in Turkey [18].

\section{Electricity Generation and Consumption Potential in Diyarbakır Province}

According to the statistics of the Turkish Statistical Institute, while 2004.5 MW of energy was generated at HEPPs established in Diyarbakır province in 2005, this figure reached $2250 \mathrm{MW}$ in 2017. Electricity generation capacity is given in Tab. 7.1 [18]. 
Table 7.1 Electricity generation capacity in Diyarbakır in 2005 [24]

\begin{tabular}{lcccc}
\hline Area & $\begin{array}{c}\text { Hydraulic } \\
\text { (MW) }\end{array}$ & $\begin{array}{c}\text { Thermal } \\
(\mathbf{M W})\end{array}$ & $\begin{array}{c}\text { Total Capacity } \\
\text { (MW) }\end{array}$ & $\begin{array}{c}\text { Ratio of Total Electricity } \\
\text { Generation Capacity to Turkey } \\
(\%)\end{array}$ \\
\hline $\begin{array}{l}\text { Diyarbakır } \\
\begin{array}{l}\text { South- } \\
\text { eastern }\end{array}\end{array}$ & 2004,5 & - & 2004,5 & 6 \\
$\begin{array}{l}\text { Anatolia } \\
\text { Turkey }\end{array}$ & 4813,4 & 375,7 & 5189,1 & 14 \\
\hline
\end{tabular}

As it can be seen from the table above, the electricity generated, by hydraulic energy source, in Diyarbakır Province, without using the potential of renewable energy sources, especially solar energy, is only $6 \%$ of the total generation capacity of Turkey in 2005. Electricity consumption according to usage places is given in Tab. 7.2.

Table 7.2 Electricity consumption according to usage places [25]

\begin{tabular}{|c|c|c|c|}
\hline Type of Consumption & Diyarbakır & $\begin{array}{c}\text { South-eastern } \\
\text { Anatolia }\end{array}$ & Turkey \\
\hline $\begin{array}{c}\text { Industrial Plant * } \\
\text { (MWh) }\end{array}$ & 256473 & 5584381 & 97777468 \\
\hline $\begin{array}{l}\text { Offices } \\
\text { (MWh) }\end{array}$ & 249284 & 1586622 & 39748278 \\
\hline $\begin{array}{l}\text { House } \\
\text { (MWh) }\end{array}$ & 453871 & 2772524 & 46189693 \\
\hline $\begin{array}{c}\text { State Office } \\
\text { (MWh) }\end{array}$ & 192533 & 938743 & 8039266 \\
\hline Agricultural Irrigation (MWh) & 62888 & 284288 & 3919119 \\
\hline $\begin{array}{c}\text { Street Lighting } \\
\text { (MWh) }\end{array}$ & 18537 & 181190 & 3942641 \\
\hline $\begin{array}{c}\text { Other } \\
\text { (MWh) }\end{array}$ & 249237 & 1332516 & 7758613 \\
\hline $\begin{array}{c}\text { Total Consumption*** } \\
\text { (MWh) }\end{array}$ & 1482825 & 12680264 & 207375078 \\
\hline $\begin{array}{c}\text { Ratio of Total Consumption to } \\
\text { Turkey }(\%)\end{array}$ & 1 & 7 & 100 \\
\hline \multicolumn{4}{|c|}{$\begin{array}{l}\text { *Construction site consumption is in the industria } \\
* * \text { Totals can be different due to rounding. } \\
\text { When we analyse the electricity consumption figures acc } \\
\text { electricity consumption is the highest in the houses. } \\
\text { corresponds to } 1 \% \text { of the total electricity consumption o } \\
\text { and economic development are low. Electricity consumpt } \\
\text { Table 7.3 Electricity consumption per capita [25] }\end{array}$} \\
\hline $\begin{array}{cc} & \text { Industrial } \\
& \text { Electricity } \\
\text { Area } & \text { Consumption Per } \\
& \text { Capita }(\text { KWh })\end{array}$ & $\begin{array}{c}\text { Residential } \\
\text { Electricity } \\
\text { Consumption } \\
\text { Per Capita } \\
\text { (KWh) }\end{array}$ & $\begin{array}{l}\text { Total Electricity } \\
\text { Consumption } \\
\text { Per Capita } \\
\text { (KWh) }\end{array}$ & $\begin{array}{l}\text { The Ratio of } \\
\text { Electricity } \\
\text { Consumption } \\
\text { Per Capita to } \\
\text { Turkey (KWh) }\end{array}$ \\
\hline Diyarbakır & 278 & 907 & 34 \\
\hline $\begin{array}{l}\text { South- } \\
\text { eastern } \\
\text { Anatolia }\end{array}$ & 336 & 1537 & 58 \\
\hline Turkey & 594 & 2669 & 100 \\
\hline
\end{tabular}


The low industrial electricity consumption per capita in Diyarbakır coincides with the previous table and clearly shows that the industrial sector is quite low in the province.

\section{Conclusions}

As a result of this study, it is seen that Turkey does not use its potential of renewable energy sources favourably; it imports oil and natural gas in order to meet the increasing demand for energy and is paying high amounts for it. It is also seen that the situation for Diyarbakır, which is especially rich in solar and hydraulic energy sources potential, is not different.

The energy need of Diyarbakır province is increasing gradually, as in the whole country due to factors such as population increase, growth and manufacturing activities. This need is mainly ensured by consumption of oil and natural gas, which also reflects external dependency. A considerable amount of money is paid abroad for purchasing these energy sources

The import dependency rate of Turkey and also Diyarbakır on petroleum is above $90 \%$. Therefore it is necessary to invest in renewable energy resources. Increasing use of renewable energy resources in Diyarbakır causes a decrease in the use of fossil based fuels. This causes a significant decrease in outflow of foreign exchange paid for fossil- based fuels.

Thanks to its rich water potential and solar intensity, Diyarbakır can provide not only its own energy needs but also the energy for neighbouring cities with the energy generated from these renewable energy sources. It is clear that this will provide significant contributions to the both the economy of the province and the country.

Accordingly, it has been concluded that the renewable energy potential in Diyarbakir is on an important level in terms of solar energy and all electricity needs in Diyarbakır and even neighbouring cities can be met by solar power plants to be established in Diyarbakir and this will provide a major contribution to the provincial economy. In terms of using this potential, local authorities, Dicle University, the trade associations and the other organizations in the city need to closer cooperate.

\section{REFERENCES}

[1] Istanbul Technical University, Energy and Its Future in Turkey, ITU Perspective, Istanbul, Turkey, 2007, http://www.emo.org.tr/ekler/34b920665683112_ek.pdf?tipi=6\&sube in Turkish.

[2] United Nations Department of Economics and Social Affairs, Population Division, World Population Prospects, The 2017 Revision.

[3] Karacadağ Development Agency, Solar Energy - Potential and Needs. TRC 2 (Diyarbakır Şanlıurfa) Region Renewable Energy Report, Diyarbakır, Turkey, 2010 in Turkish.

[4] Turkey Statistical Institute (TUIK). Foreign Trade Statistics, http://www.tuik.gov.tr/PreTablo.do?alt_id=1046 in Turkish.

[5] Turkey Petroleum Strategy Development Department, Crude Oil and Natural Gas Sector Report, http://www.enerji.gov.tr/File/?path=ROOT\%2F1\%2FDocuments\%2FSekt\%C3\%B6r\%20Raporu\%2F TP_HAM_PETROL-DOGAL_GAZ_SEKTOR_RAPORU_2015.pdf in Turkish.

[6] Bayrak, M., Esen, Ö., Turkey's Energy Deficit Problem and Quest for Solution, Ataturk University Journal of Economics and Administrative Sciences, 28 (2014),3, pp.141-142 in Turkish.

[7] General Directorate of Renewable Energy, Solar, http://www.eie.gov.tr/MyCalculator/pages/21.aspx in Turkish. 
[8] Varınca, K. B., Gönüllü, M.T. A Study on Method, Prevelance and Degree of Solar Energy Potential and Using this Potential in Turkey, UGHEK'2006: First National Solar and Hydrogen Energy Congress, Eskişehir, Turkey, 2006, p. 272 in Turkish.

[9] Yilmaz, M., Turkey's Energy Potential and The Importance of Renewable Energy Sources in terms of Electricity Generation, Ankara University Journal of Environmental Sciences 4 (2), 2012, pp. 44, http://dergiler.ankara.edu.tr/dergiler/47/1924/20179.pdf in Turkish.

[10] Kapluhan, Erol, An Study in Terms of Energy Geography: Use of Solar Energy in Turkey and in the world. Geography Magazine Issue 29, 2014, pp. 70-98, http://istanbul.dergipark.gov.tr/download/article-file/231256 in Turkish.

[11] General Directorate of Renewable Energy, Wind, http://www.eie.gov.tr/yenilenebilir/ruzgar.aspx, http://www.eie.gov.tr/YEKrepa/DIYARBAKIR-REPA.pdf in Turkish.

[12] Turkey Ministry of Energy and Natural Resources (MENR), 2016 http://www.enerji.gov.tr/trTR/Sayfalar/Jeotermal in Turkish.

[13] Turkey Ministry of Energy and Natural Resources (MENR), 2017 http://www.enerji.gov.tr/trTR/Sayfalar/Biyokutle in Turkish.

[14] General Directorate of State Hydraulic Works, 2015 Annual Activity Report, Ankara, Turkey, 2015 http://www.dsi.gov.tr/docs/stratejik-plan/dsi-2015-faaliyet-raporu.pdf?sfvrsn=2 in Turkish.

[15] Usta, R,, Turkey's Renewable Energy Strategy and Policy, General Directorate of Renewable Energy, http://www.tepav.org.tr/upload/files/haber/1427476175-0.Ramazan Ustanin Sunumu.pdf in Turkish.

[16] Kılıç, H., Gümüş, B., ve Yılmaz, M., Measurement and Analysis of Solar Energy Data According to Meteorological Standarts for Diyarbakır Province, EMO Scientific Journal, Vol. 5, 2015, No 10, pp. 47-52 in Turkish.

[17] Bulut, H., Büyükalaca, O., Analysis of Solar Data for Diyarbakır Province and Derivation of Typical Solar Radiation Values, (III.GAP and Industry Congress), Chamber of Mechanical Engineers, Diyarbakır, Turkey, 2003 in Turkish.

[18] Energy Atlas, E - Bulletin, 2016, www.enerjiatlasi.com in Turkish.

[19] General Directorate of Renewable Energy, Geothermal,

http://www.eie.gov.tr/yenilenebilir/jeotermal.aspx in Turkish.

[20] Çermik Municipality, Geothermal Energy Source Located in Çermik, Diyarbakır, Çermik Municipality Geothermal Energy Report, Diyarbakır, Turkey, 2017 in Turkish.

[21] Eliçin, A.K., Aydın, İ., ve Gezici, M., Potential and Use of Renewable Energy in Agricultural Origin in Diyarbakır, Poster, 29th National Mechanization and Energy Congress, Diyarbakır, Turkey, 2015, pp. 4-5 in Turkish.

[22] General Directorate of Renewable Energy, Hydraulic, http://www.eie.gov.tr/yenilenebilir/hidrolik.aspx in Turkish.

[23] Kurtuluş, A. B., Y1lmaz, Ender., ve Atmaca, Mustafa., Analyzing of the Energy Situation of Diyarbakir, Proceedings, $2^{\text {nd }}$ Anatolian Energy Symposium, Diyarbakir, Turkey, 2013

[14] Turkey Statistical Institute (TURKSTAT). Regional Statistics, https://biruni.tuik.gov.tr/bolgeselistatistik/tabloOlustur.do\# in Turkish.

[25] Turkish Electricity Distribution Company (TEDAŞ), Turkey Electricity Distribution and Consumption Statistics, 2014 in Turkish. 